\title{
Transnational policy networks and change through internationalization (The Record of Project 5-100)
}

Article

Published Version

Crowley-Vigneau, A., Istomin, I. A., Baykov, A. A. and Kalyuzhnova, Y. ORCID: https://orcid.org/0000-0002-57818837 (2021) Transnational policy networks and change through internationalization (The Record of Project 5-100). Polis. Political Studies (5). pp. 8-24. ISSN 1026-9487 doi: https://doi.org/10.17976/jpps/2021.05.02 Available at https://centaur.reading.ac.uk/100614/

It is advisable to refer to the publisher's version if you intend to cite from the work. See Guidance on citing.

Identification Number/DOI: https://doi.org/10.17976/jpps/2021.05.02

$<$ https://doi.org/10.17976/jpps/2021.05.02>

Publisher: Political Research

All outputs in CentAUR are protected by Intellectual Property Rights law, including copyright law. Copyright and IPR is retained by the creators or other copyright holders. Terms and conditions for use of this material are defined in the End User Agreement. 


\section{CentAUR}

Central Archive at the University of Reading

Reading's research outputs online 
DOI: $10.17976 / \mathrm{jpps} / 2021.05 .02$

\title{
TRANSNATIONAL POLICY NETWORKS
}

\section{AND CHANGE THROUGH INTERNATIONALIZATION (The Record of Project 5-100)}

\author{
A. Crowley-Vigneau ${ }^{1}$, I.A. Istomin ${ }^{1,2}$, A.A. Baykov ${ }^{1,3}$, Y. Kalyuzhnova ${ }^{3}$ \\ ${ }^{1}$ Moscow State Institute of International Relations. Moscow, Russia \\ ${ }^{2}$ Davis Center, Harvard University. Cambridge, Mass., U.S.A. \\ ${ }^{3}$ Centre for Euro-Asian Studies, Henley Business School. Reading, UK
}

CROWLEY-VIGNEAU Anne, Doctor in Management, Cand. Sci. (Pol. Sci.), Associate Professor, MGIMO University, email: vigneau.a@my.mgimo.ru; ISTOMIN, Igor Alexandrovich, Cand. Sci. (Pol. Sci.), Associate Professor, MGIMO University; Senior Visiting Scholar, Davis Center, Harvard University, email: i.istomin@inno.mgimo.ru; BAYKOV, Andrey Anatolyevich, Cand. Sci. (Pol. Sci.), Vice-Rector, Dean, Faculty of International Relations, MGIMO University; Visiting Professor, Henley Business School, email: baykov@mgimo.ru; KALYUZHNOVA, Yelena, Doctor in Economics, Professor, Director of the Centre for Euro-Asian Studies, Henley Business School, email: y.kalyuzhnova@henley.ac.uk

Crowley-Vigneau A., Istomin I.A., Baykov A.A., Kalyuzhnova Y. Transnational Policy Networks and Change Through Internationalization (The Record of Project 5-100). - Polis. Political Studies. 2021. No. 5. P. 8-24. https://doi.org/10.17976/jpps/2021.05.02

Received: 15.03.2021. Accepted: 20.05.2021

\begin{abstract}
This article considers the ideational and political contexts in which Project 5-100, the Russian excellence in higher education initiative emerged, as well as the specificities of its organisational and behavioural model. While Project 5-100 has been studied in the academic literature as regards its efficiency and how it affected the performance and inner workings of the participating universities, the question of how the project came about and the characteristic traits of its internal set-up still remain largely overlooked. The study focuses on the involvement of local and international players, arguing that their successful and organic cooperation influenced both the architecture and the implementation of the project. This paper contributes to the literature on policy networks by showing that transnational actors do not necessarily undermine or challenge state power and can on the contrary help governments implement systemic change. Inspired by the international experience of establishing world-class universities, Project 5-100 was conceived and lobbied by a small but influential group of visionaries pushing for change who - acting in a concerted and purposive manner - acquired a novel and powerful capacity to use international expertise for the development of a key national project, capable of deeply transforming the country's higher educational system.
\end{abstract}

Keywords: Russia, Project 5-100, higher education, internationalization, Transnational Advocacy Networks (TANs), Transnational Expertise and Experience Networks (TEENs).

As Project 5-100 grinds to a close in 2021, the time is ripe to take stock of both the reasons for the launch of this initiative and its principal features. Project 5-100 is a major policy initiative to increase international competitiveness of the Russian higher education and science. The analysis of its design, of what sets it apart from previous efforts and the type of support that was necessary to carry it out are topics of interest for both scholars and policy-makers. The authors retrace the process that led to the adoption of Project 5-100 and gauge the contribution of a multitude of actors to the initiative.

The study focuses on the contribution of local and international players, arguing that their successful and organic cooperation impacted both the architecture and the 
implementation of the project. It relies on the literature on policy networks to examine horizontal ties between actors located in various structural positions and possessing diverse sets of competences, arguing that emerging web of stakeholders on the national and university levels played a critical role in introducing systemic change. It emphasizes the role of transnational connections in promoting the model of internationalized, research-oriented university. Thus, the authors identify such entities as the 5-100 Project Office, the International Expert Committee, International Advisory Boards within universities, rating agencies, external consultants and international experts as central nodes of the Transnational Expertise and Experience Network [Crowley-Vigneau, Baykov, Kalyuzhnova 2020], which contributed to the capacity-building and international competitiveness of selected Universities. The paper contributes to the literature on policy networks by showing that transnational actors do not necessarily undermine state power and can, on the contrary, help the government bring about systemic change.

A detailed analysis of 12 interviews (Appendix 1) conducted with experts involved in designing and implementing Project 5-100 enables the authors to generate a vision of the project "from within". The interviews provided the authors with unpublished factual details concerning the organization of the project and with a subjective perception of its main advantages and drawbacks. By presenting the views of various stakeholders, this article has two main goals: first, to reconstruct a reliable genealogy of the initiative, introducing new information such as who were its masterminds; why such an ambitious goal (5 Russian universities in the top 100 global institutional rankings) was selected and which foreign players were involved in sharing international best practices. Second, the article identifies the organizational characteristics and structural elements that made the project efficient and those that slowed its progress; thus informing future debates on the features, which make any similar initiatives efficacious. The main finding of the paper is that 'excellence in higher education' initiatives require the involvement of international networks from their conception to their implementation. A detailed structural analysis of Project 5-100, the conditions and main actors involved in its emergence and its implementation highlights the importance of both spontaneous and government-sponsored networking in helping it achieve its internationalization goals.

\section{POLICY NETWORKS AND TRANSNATIONAL DIFFUSION}

The Cambridge Dictionary defines a network as "a large system consisting of many similar parts that are connected together to allow movement or communication between or along the parts, or between the parts and a control centre" ${ }^{1}$. Scholars showed interest to such horizontal connections for a long time, but the debate on the role of policy networks experienced a major surge since the 1990s (for an overview of the literature, see [Rhodes 1997; Börzel 1998; Smorgunov 2001; Enroth 2011]). Moreover, the emergence of specialized textbooks testifies to the maturation of the field [Mikhailova 2013; Network Analysis of Public Policy 2013].

The literature on networks associates policy change with shifts in the composition of involved agents. It presents decision-making as the final result of negotiations between individuals. Therefore, it focuses on the connections between actors rather than on formal rules, stages of policy cycle, or psychology of political leadership. In this regard, it falls within the pluralist tradition of Political Theory.

\footnotetext{
${ }^{1}$ Cambridge Dictionary. URL: https://dictionary.cambridge.org/ru/ (accessed 20.07.2021).
} 
The research on policy (or issue) networks emerged from the dissatisfaction with the failures to restrict policy-making to closed communities (such as 'iron triangles', see, [Heclo 1978]). It emphasized the multiplicity and diversity of stakeholders involved in shaping political decisions. Networks incorporate actors operating from positions within the government and various players influencing policy process from the outside, demonstrating the limited role of this in-out division.

Scholars recognize the dualistic nature of policy networks, which structure relations between agents involved in decision-making and at the same time operate as agents themselves [Marsh, Smith 2000]. The focus on networks becomes especially appropriate for examining cases defined by horizontal ties between actors (as opposed to direct subordination) and potential changes in the composition of involved actors. These are two conditions that are present in the evolution of Project 5-100.

The emergence of networks reflects the reliance of policymaking on a set of resources, including legal authority, political legitimacy and issue-related expertise. As no single actor possesses the full spectrum of required competencies, stakeholders become dependent on each other to secure preferred outcomes and need to cooperate. This interdependence becomes a precondition for holding the network together [Bevir 2009: 114]. Through establishing connections and pursuing coordinated actions its participants foster policy ideas that they share.

Much of the research on networks restricts the analysis to the coordination of local stakeholders within a given country, as it flourished within the subfield of public policy analysis (see, [Adam, Kriesi 2007]). However, International Relations specialists demonstrated the ability of transnational actors to affect policies on the state level through horizontal coordination. The literature primarily accentuates the contribution of Transnational Advocacy Networks (TANs) pressuring authorities to adopt internationally prescribed standards of behaviour [Keck, Sikkink 1998]. Meanwhile, recent studies pointed to the importance of transnational connections in policy implementation.

At this stage, their main impact lies in the provision of expertise and know-how rather than raising general awareness and redefinition of values. Therefore, it is more appropriate to designate them as Transnational Expertise and Experience Networks (TEENs) rather than TANs [Crowley-Vigneau, Baykov, Kalyuzhnova 2020]. While the same actors that operated during policy adoption may remain involved in implementation, TEENs, because of their different mission, usually consist of other types of players. By looking at the adoption and implementation of policies, the analysis on Project 5-100 will further contribute to the empirical validation of the role of these groupings. More broadly, insight into the operations of TANs and TEENs will highlight the relevance of IR scholarship for the literature on policy networks.

The burgeoning research on transnational networks focuses heavily on the part non-state actors play in spreading ideas, norms and practices across state borders (such emphasis dates to the foundational Constructivist writings in the 1990s, see [Finnemore 1996; Finnemore, Sikkink 1998; Keck, Sikkink 1998]). After the end of the Cold War, it helped to legitimize the concept of global civil society, organized around horizontal cooperative ties of political activists [Eschle 2001; Keane 2003; Globalizing Civic Engagement... 2012; The Third Force... 2012]. In many cases these networks were viewed as antithetical to the authority of states, with Mary Kaldor claiming: "the growing interconnectedness of states, the emergence of a system of global governance, and the explosion of the movements, groups, networks and organizations that engage in a global or transnational public debate, have called into question the primacy of 
states" [Kaldor 2003: 583]. This perspective correlates with the claims in the domain of public policy analysis that proliferation of networks led to the replacement of government with governance [Rhodes 1997: 57].

This presumption reflects the Liberal perspective of viewing state-society relations as inherently conflictual and seeking the emancipation of individuals from the tyranny of governmental authority (ironically, this view of horizontal organizations as counterbalance to a class-dominated state shared Marx and his revolutionary disciples). However, alternative intellectual traditions taking roots in writings of such dissimilar thinkers as Hegel and Gramsci often view state and social organizations as mutually complementary and reinforcing (despite axiological differences regarding the desirability of such a conjunction).

Therefore, it is an inversion of the initial intellectual promise of network theory claiming that agency in policymaking spread beyond the state to argue that it is always or even primarily goes against state power. Conversely, the theoretical provisions regarding the roots of change suggest that networks can empower policies preferred by national authorities through instrumentalizing the resources of transnational contributors. The Project 5-100 serves as a case of policy change, which the government long sought but lacked access to the relevant competences. Only through importing resources through transnational connections it managed to advance its preferences.

The sustained interest in policy networks resulted in the introduction of specialized methods to assess their composition and operation. Much attention is devoted to the quantitative network analysis, applying various metrics to identify crucial nodes or overall layout (see, for example, [Hafner-Burton, Kahler, Montgomery 2009; Degterev 2015]). Nevertheless, in this article, we pursue the qualitative analysis of the networks involved in adopting and implementing Project 5-100. This methodological choice reflects essential differences in the contribution of various actors to policy-making both on the national level and within involved universities as well as difficulties in their quantification. Meanwhile, careful process-tracing provides valid instruments for identifying the role of relevant stakeholders [Process Tracing 2015].

\section{ADOPTION OF PROJECT 5-100}

The internationalization of Russian universities began in the 1990s with Moscow embarking on a sweeping liberalisation of higher education, motivated by the need to adapt universities to the demands of the market and of modern society [Gutorov 2015]. Its subsequent participation in the Bologna process in the 2000s, the implementation of higher education initiatives in cooperation with international organizations such as the EU and the World Bank, the launch of the Russian Federal Universities and National Research Universities projects [Smolentseva 2015: 399-403] reflect the long-standing government interest in internationalising the country's universities but also its inability to effectively change the higher education system.

The launch in 2012 of Project 5-100, however, marks a distinct rupture point with previous initiatives as it was for the first time primarily focused on making Russian universities globally competitive and manifestly relied on foreign metrics - international ratings and bibliometric data - to evaluate their performance [Agasisti et al. 2018: 275]. In spite of the scholarly interest surrounding Project 5-100, little information has been published regarding the conditions, which led to its creation. The conduct and deciphering of semi-structured expert interviews enabled the authors to recreate the genealogy of Project 5-100 and identify its main ideologues, champions, and proponents. 
The idea that a novel internationalization initiative is necessary was conjured up in a small group of Russian universities (some of which did not subsequently join the project): notably HSE, MGIMO, MISiS, $\mathrm{MEPhi}^{2}$. A network of leading personalities, experts in higher education, policymakers, and university management figures met at different times and venues to discuss their desire for change and what it was going to take to translate their vision into reality. The group purportedly included four key actors: (1) Andrey Fursenko, Minister of Education from 2004 to 2012, currently Aide to the President of Russia overseeing Science and Education; (2) Alexander Povalko, who served from 2008 to 2012 as Deputy Head of the State Committee on Youth Issues in Russia and Deputy Head of the Federal Agency on Youth Issues to become in 2012 (until 2016) Deputy Minister of Education and Science of the Russian Federation; (3) Dmitry Livanov, Deputy Minister of Education from 2005 to 2007, who became in 2007 Rector of MISiS and then was appointed Minister of Education on the 21st of May 2012; (4) Andrey Volkov, the Rector of the Skolkovo School of Management who worked as an advisor to the Minister of Education and supervised a group of experts from the G8 countries studying Russian educational initiatives ${ }^{3}$. These four experienced individuals with robust international ties constituted the very core of the group that lobbied for the creation of a new excellence in higher education program in Russia.

This network also comprised academics, businesspeople, policymakers, and subject-matter experts. Jamil Salmi of the World Bank who had previously authored two highly influential publication on world-class universities [Salmi 2009; Altbach, Salmi 2011] actively contributed to the project. The Russian scholar from the Higher School of Economics Isak Froumin who had previously worked at the WB and the government advisor Irina Karelina also offered their expertise. The Vice-Rector at MISiS Timothy O'Connor who had been in close interaction with Dmitry Livanov before the latter became Minister of Education also had an important influence on the development of Project 5-100.

The Higher School of Economics and Skolkovo School of Management were the most dynamic hubs, which hosted a series of meetings resulting in the decree of May 7th 2012. The key members of the policy-making network (see Fig. 1) came together for several informal meetings in Skolkovo School of Management concerned with discussing the features of a new project for Russian universities that would propel them forward in global rankings (Interviews 1, 3 and 12).

The personalities making up the network had tight links with the government, working as Advisors to Ministers and in governmental committees related to education or being part of the government itself. According to existing accounts, Dmitry Livanov and the Rector of the Higher School of Economics Yaroslav Kuzminov were among the experts who did most of the convincing within the Presidential Administration that two of the conditions for its success were for it to be competitive and based on international benchmarks. Dmitry Livanov's role was described by several interviewees as essential ("He may not have invented it single-handedly but the 5-100 program was his doing: he argued for it, lobbied for it, made his way through the Russian

\footnotetext{
${ }^{2}$ HSE - National Research University - Higher School of Economics; MISiS - National University of Science and Technology MISIS; MEPhI - National Research Nuclear University - Moscow Engineering Physics Institute (ed.).

${ }^{3}$ Skolkovo Education Development Centre. 2020. URL: https://sedec.skolkovo.ru/en/sedec/ (accessed 23.09.2020).
} 
bureaucracy to sell it" (Interview 4). Upon becoming Minister of Education in 2012, Dmitry Livanov made Project 5-100 one the key features of his tenure.

Figure 1

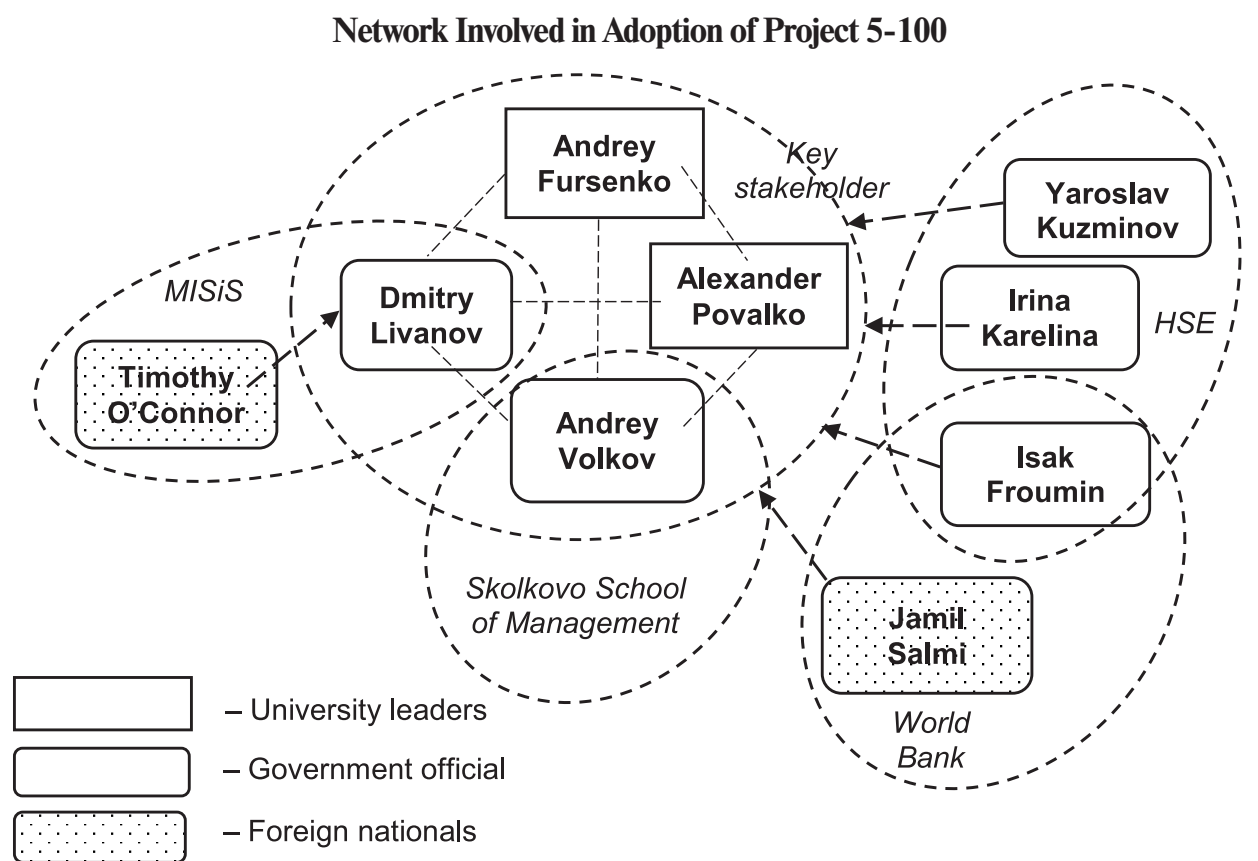

Source: authors.

The Presidential Decree of the Russian Federation No. 599 of May 7th, 2012 "On measures to realize state policy in the sphere of education and science" marked the official launch of the Russian Academic Excellence Project, more commonly referred to as Project 5-100. From the outset, the project was government-run and aimed to enhance the international competitiveness of the Russian higher education system. The May 7th, 2012 decree is a high-level document which only sets forth the ultimate target: to bring at least 5 Russian universities into the top 100 world universities by 2020, as per the global university rankings (QS, Times Higher Education, and Shanghai University Ranking). This target was part of the May Decrees signed by Vladimir Putin on the first day of his return to the Presidency, and which cover a vast array of topics.

The decree was followed by the Government Order No. 2006-r of October 29th, 2012, detailing the governmental action plan to reach the announced targets.

The funds allocated to the project were defined in the Government Order No. 211 of March 16th, 2013 on "Measures of government support for leading Russian universities to increase their competitiveness among the world's leading research and education centers": 9 billion rubles in 2013, 10.5 billion in 2014, 10.5 billion in 2015 , 11.1 billion in 2016, 10.5 billion in 2017, 10 billion rubles in 2018, 10 billion in 2019 and 10.2 billion rubles in $2020^{4}$.

\footnotetext{
${ }^{4}$ Government Decree No. 211 of 16 March 2013 on measures of government support for leading Russian universities to increase their competitiveness among the world's leading research and education centers. URL: https://5top100. $\mathrm{ru} / \mathrm{en} /$ documents/regulations/74083/ (accessed 23.09.2020).
} 
The people aspiring to promote the new project for the internationalization of higher education in Russia accomplished their immediate goal with the signing of the May 7th 2012 Presidential Decree and the subsequent regulations. They managed to achieve this result by combining their administrative authority, political persuasiveness, and issue-related expertise. The network involved in policy adoption mostly consisted of Russian state officials, university leaders and experts, but they also relied on the assistance of foreign nationals who helped to define the scope and essential components of the Project 5-100. However, the advocacy group, which could be analysed as a TAN, did not retreat at that early stage, as the design of the project (apart from the final target) was largely undefined.

A few key meetings took place from May to October 2012 with the participation of three or four members of the core of the policy network: Dmitry Livanov who had already become Minister of Education, Alexander Povalko who became Deputy Minister of Education, Andrey Fursenko (as the key figure in charge of Higher Education in the Presidential Administration) and Andrey Volkov as an external consultant. The need for external council soon became apparent and the team arranged a meeting with the expert Jamil Salmi, who repeatedly visited Russia during the course of 2012 and penned a concept note about how the new program should be managed (Interview 7). The World Bank, thus, acted as an influential vector of change and was called upon directly to help design the project (Interview 2).

\section{STRUCTURAL ORGANIZATION OF PROJECT 5-100}

This section describes the structural organization of Project 5-100, revealing how the initiative was framed from its outset to promote international exchanges of best practices and support transnational networking (see, Fig. 2).

While the Ministry of Education had a team of 5 people, supervising all higher education projects, including Project 5-100, the project was de facto run by a standalone entity, the 5-100 Project Office, which is the main government working force behind the realization of the project. The Project Office was established as a relatively flexible entity capable of processing the requests of the Ministry but also dynamically interacting with the participating universities and seeking out help of foreign actors. Alongside following-up on the performance of participating universities and checking the transparency of the spending, the Project Office also assumes public diplomacy tasks including increasing the visibility of Russian universities worldwide and improving their global reputation by participating in forums and fairs, holding joint expositions with ranking companies such as QS and Times Higher Education (Interview 1). The tasks assigned to the Project Office require that its employees constantly communicate formally and informally with international experts, consultants from preparing the International Expert Committee meetings to attracting foreign experts over to Russia to help universities refine their strategies (Interview 11). The Project Office also convenes conferences in Russian universities with the participation of representatives of Web of Science, Scopus, the OREGA forum and the company Bright Consulting. The Project Office appears as a central node of the network involved in implementing Project 5-100, creating a platform for interaction between national and foreign actors. 
Network Involved in Implementation of Project 5-100 at National Level

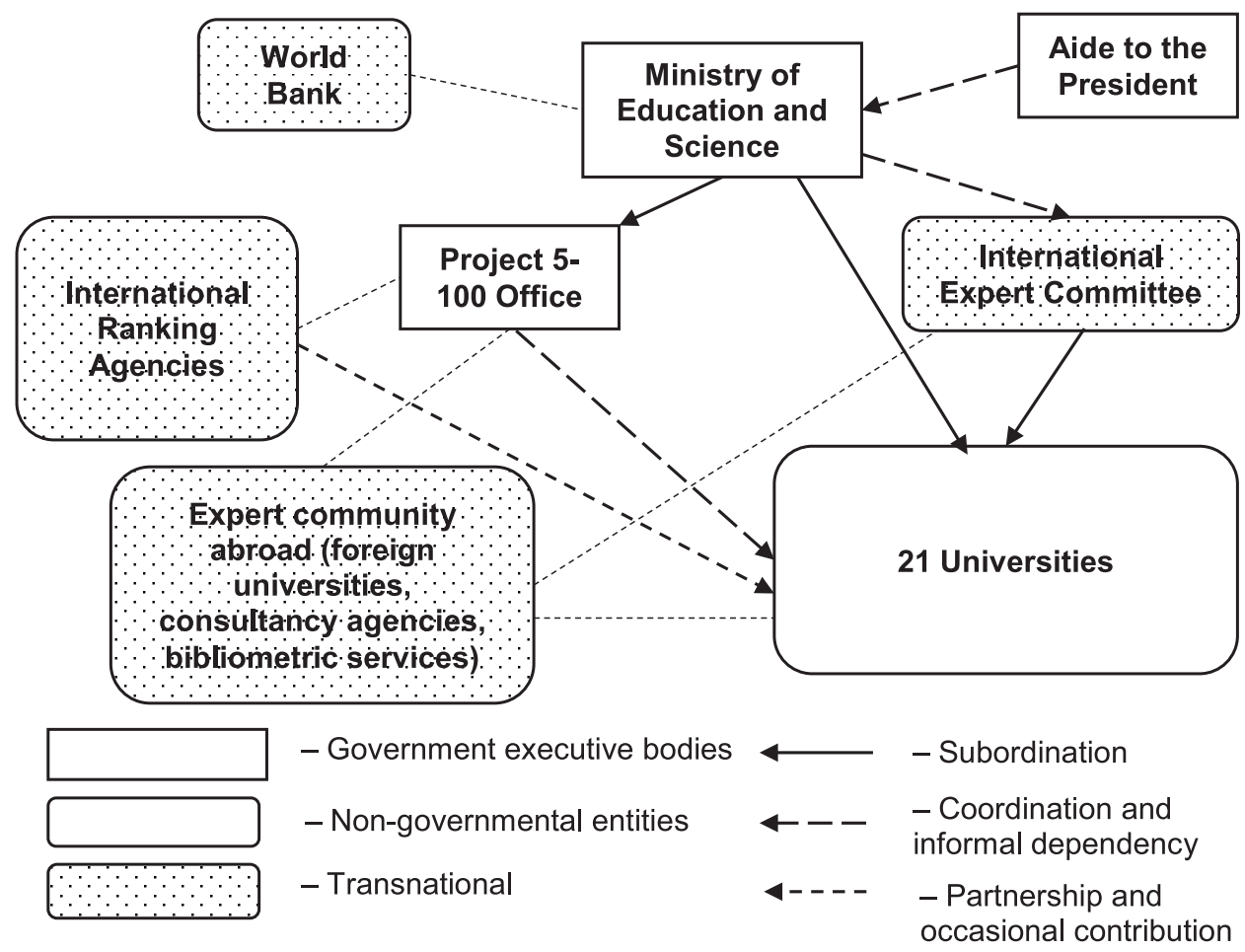

Source: authors.

Another key nod of the network is the International Expert Committee which is the main authority in the selection of universities to participate in the project and meets at regular intervals to oversee the development of these universities. The Committee includes experts from Russia and abroad in various fields, scholars, public officials who have experience in the development of education. It goes over the universities' roadmaps, decides what funding is needed to implement these goals and then communicates to the Russian Ministry of Education and Science what measures need to be taken. In 2020, seven members of the Committee were Russian, six were foreigners from China, the UK, the U.S.A. 5 .

Expert interviews reveal that the main advice offered by the Committee to Universities was: to be more realistic in their roadmaps, to be less complacent and to speak about their difficulties instead of flaunting their realizations, to make changes in management when necessary in order to successfully carry out change, to improve tertiary education and online education, to use external consultants to get an objective look at the situation in the university, to enrol more foreign students, to increase the number of academic mobility programs, to work on re-branding and marketing their educational programs, to develop fundamental research in partnership with international and Russian partners (Interviews 1, 6, 9, 10). The International Expert Committee is a central feature of Project 5-100 as it includes foreigners with extensive

${ }^{5}$ 5-100 Council Members. 2020. URL: https://5top100.ru/en/council/ (accessed 23.09.2020). 
practical experience of helping universities rise in international rankings and brings them in interaction with university representatives.

Participating universities were also required to create International Advisory Boards. These boards are collegial bodies that provide strategic and management advice to universities. A common practice in universities around the world, they feature leading scholars and experts with a significant management experience in the field of education. They include on average ten to twelve members who meet once a year for a few days to discuss how the university is progressing. A key challenge during the constitution of the International Advisory Board is to convince a prominent personality to join or preside over the Committee, which makes it easier to get other experts on board (Interview 5). Many universities were successful in this endeavour with the Higher School of Economics boasting Harvard Professor and Nobel Prize in Economics Eric Maskin as its Board Chairman and MFTI ${ }^{6}$ Rafael Reif, the Rector of MIT. HSE has on its Board Philip Altbach one of the most prominent experts on higher education, and professors and policymakers from the U.S., China, Ireland, India and Brazil. International Advisory Boards make university management accountable to international experts but also promote experience-sharing and networking.

\section{IMPLEMENTATION OF PROJECT 5-100}

Having reviewed the emergence and structural organization of Project 5-100, the authors consider how the actors networked and contributed to the sharing of international best practices.

The International Expert Committee appears as the most influential international actor in rolling out Project 5-100. While the very existence of the Committee reflects the international dimension of Project 5-100, its impact can be best gauged by analyzing the contribution of its members.

Malcom Grant, Chancellor of the University of York and member of the International Expert Committee since the start of the project, was mentioned by half of the respondents, testifying to the extent of his influence on the Committee's decisions. Malcom Grant has been praised for his active contribution during the project's steering committees and several interviewees agreed that the originality and the impact of his comments determined the course of the strategy of several universities. One interviewee picked up on his ability to identify and predict issues: "Malcom Grant asked how we were going to change the organizational culture in the University. The question was valid and I realized later how right he was, as it was difficult to explain the need for change to everyone at the university and there was a lot of stagnation and even resistance" (Interview 10).

Russian university management had to change its presentation format to adapt it to an international audience, adopting a modest tone, owning up to its shortcomings and asking for strategic advice. The requirement that presentations be delivered in English was surprisingly a stumbling block for the management of some universities and for members of the ministry. While a number of interviewees admitted how challenging it was to work in a foreign language, most recognized the benefits of being forced out of their comfort zone (Interviews 4 and 7).

The recommendations of the Committee fell into several categories: to strengthen leadership skills, to assess whether the allocated funding is sufficient to

\footnotetext{
${ }^{6}$ MFTI - National Research University - Moscow Institute of Physics and Technology (also known as PhysTech) (ed.)
} 
successfully carry out an initiative, to choose priority focus areas, to develop brand and marketing activities. The leadership of some universities came under harsh criticism for effectively blocking any attempts at change. This is why the Committee strongly promoted managerial reshuffles within universities and even staff exchanges between universities.

Other interviews underscored the role of the International Expert Committee in sharing best international practices, pointing out that some of its members were foreigners with practical experience of helping universities rise in international rankings. Another quality of the foreign members of the Committee was their ability to be objective and "to say things, which Russians might not feel comfortable saying" (Interview 2).

External consultancy firms also played an important part in Project 5-100, by helping universities to fine-tune their international development strategies. The main consultancy firms operating in the educational services segment in Russia have been identified as PricewaterhouseCoopers (PwC) and $\mathrm{Mc} \mathrm{Kinsey}^{7}$, with the majority of 5-100 universities having employed the services of one or both companies. These agencies made a name for themselves on the Russian market for advisory services to universities before the launch of Project 5-100. A respondent noted that $\mathrm{PwC}$ was a motor for change and internationalization at MISiS and that starting from 2010 a long-lasting partnership developed between MISiS and PwC (Interview 4).

The consultants rendered a broad range of services including performing research and analytics, preparing data and benchmarks and drawing up competitive strategies. Several respondents noted that the universities where they work would not have experienced the boom that made their success had external consultants not been involved. While this process of change took off in MISiS before the start of Project 5-100, most other universities waited for 2012 to engage consultant agencies' services. When they were preparing for the competition to join Project 5-100, universities received instructions to use external consultants to help elaborate the roadmaps they were to defend before the International Expert Committee.

Consultants' support even extended to attending the first steering committees of the project. The International Expert Committee specifically flagged up the benefits of employing consultants during the initial stages of reorganization noting that the management of most universities needed an objective view on their internal organization and that some problems were so deeply engrained that it was difficult for an insider to identify them and even more so to report them. Even though not all the consulting firms had departments dedicated to education and were knowledgeable enough to help with universities' strategic development, they aided with internationalization by putting Russian universities and faculty members in contact with universities with matching profiles abroad: for example, consultants helped forge the partnerships between MFTI, MIT and the French Ecole Polytechnique (Interview 12).

Consultancy firms proved effective because they combined several assets: an international experience at facilitating institutional change within universities abroad and an in-depth understanding of the Russian market. While according to one account, the consultants employed were all Russian citizens, most had degrees both from Russian and foreign universities and all had undergone extensive training abroad. When realizing a project, consultants frequently invite foreign experts they have

\footnotetext{
${ }^{7}$ McKinsey - McKinsey \& Company is the trusted advisor and counselor to many of the world's most influential businesses and institutions (ed.).
} 
previously worked with to make recommendations and share their strategic insights. Not only do consultants have their own international experience, they also facilitate new relationships by putting universities in contact with experts from abroad.

Consultancy agencies were actively involved in Project 5-100 because they helped shed a new light on the activities of the universities, they shared their experience of internationalization, they helped select leading global universities specializing in similar fields to inspire their development and put universities in contact with leading experts. Most universities only gained access to this international experience and expertise through Project 5-100.

Universities' International Advisory Boards likewise represent major vectors of change, providing universities with strategic advice on how to be competitive in the global educational market. Not only do these boards offer recommendations on issues relating to the internationalization of universities' activities, they also weigh in on all major strategic decisions.

As noted by the Co-Chairman of the Board of Tomsk University Terrence Vincent Callaghan, Distinguished Research Professor of the Royal Swedish Academy of Sciences and Nobel Prize winner, the board members are brand ambassadors who help the University identify and implement ways to achieve world status ${ }^{8}$. The International Advisory Board members of Tomsk University provided valuable advice based on the topics researched at the University: they recommended it focus on its unique geographical position by developing its research on environmental sciences, that it anticipate the results of climate change by assessing how changes in temperatures could impact shipping routes, that it develop partnerships with research centres and that it re-focus on delivering short-term results as ambitious long-term projects attract less funding (Interview 6). Cooperation with board members led to joint publications with researchers from Tomsk State University [e.g. Kirpotin et al. 2018].

The International Advisory Board of HSE also addresses precisely the different problems that arise and offers tailored advice on human resource, curriculum and governance issues ${ }^{9}$, referring to its members' experience tackling similar problems elsewhere. For example, the HSE board recommended that more alumni be included in the governing bodies of the University, as most private American universities are in the end governed by their alumni ${ }^{10}$.

The Board members also noted the need to integrate international students in existing classes rather than offer them a different track and to develop the practice of peer and student assessments of classes in order to promote optimal teaching methods ${ }^{11}$. These examples show that International Advisory Boards can use their experience and expertise to offer tailored advice to universities in an operational way. Their independence makes it easier for them to identify and voice concerns regarding the inner workings of a university.

Rating agencies also had an important influence on Project 5-100. They publish rankings, which are used as a reference point by the leadership of Russia to assess the

\footnotetext{
${ }^{8}$ Callaghan T. Terrence Vincent Callaghan about Tomsk State University. 2015. URL: http://en.tsu.ru/about/ international_council/international_council_documents.php (accessed 23.09.2020).

${ }^{9}$ Report on HSE International Advisory Committee meeting in Moscow. 5-6.12.2017. URL: https://iac.hse.ru/ data/2018/03/01/1165037761/IAC\%20report\%20upon\%20IAC\%20Meeting\%202017.pdf (accessed 23.09.2020).

${ }^{10}$ Ibidem.

${ }^{11}$ Ibidem.
} 
progress made by universities participating in Project 5-100. The name of the project itself directly refers to the institutional rankings. Rating agencies collect data from universities in order to create the rankings and are in constant interaction with the former. Furthermore, they are especially influential because the changes they make to the calculation methodology can significantly affect universities' position in the rankings. This dependency on rating agencies makes universities highly receptive to recommendations the former make. Universities that are intent on climbing in international rankings may seek consultations from these agencies.

The main ranking agencies that Russian universities and the government look to are QS, Times Higher Education and the Shanghai University Ranking. At the start of Project 5-100, all participating universities were anxious to find out more about the methodology used for the rankings and in some cases invited specialists from these agencies to explain how the results are calculated. Rating agencies provide commercial consultancy services to universities and governments.

Some agencies such as QS have their own consultancy branch ${ }^{12}$. QS offers a whole range of services including strategy recommendations, advice on hiring international faculty, a review of governance and structure, financial planning, advice on improving student recruitment and graduate employability, marketing and branding recommendations. The QS consultancy unit addresses all the criteria in their calculation methodology and helps universities overcome the main stumbling blocks, which hinder their progress in the global university rankings.

Rating agencies have, however, come under criticism for producing global rankings, which claim to be objective on the one hand and commercial consultancy services on the other. The impact of ranking agencies is also limited by the fact that according to some accounts they provide ready "boxed" products and do not adapt the content of their recommendations to specific universities (Interview 5).

Ranking agencies through their rankings and their company representatives have helped to promote some key messages, including the importance of international faculty and students and the need to develop research and international publications. Most interviewees claim to have met in one context or another the QS representative in Russia, Zoya Zaitseva (Interviews 1,3,4,5,8,9). Project 5-100 itself led to a heightened interest in rating agencies, with even those universities not participating in the project engaging their services.

International Experts on higher education and university-based researchers operating in Russia or interacting with Russian universities embody another important vector of change and internationalization. These experts can be foreigners or Russians with international experience, they can come from different spheres and be academics, researchers, administrators, diplomats, businesspeople, but they all have in common their expertise or work experience in the sphere of higher education.

Their influx accelerated in the 2010s with the launch of Project 5-100 and other programs, which were specifically designed to attract experts with an international experience or exceptional skills. The "Export of Education" project aims to increase the number of foreign students studying in universities in Russia and the number of people abroad enrolled in Russian online courses. These foreign students when they return home are ideal candidates for experience sharing with Russia and even during their studies (because they arrive with certain expectations), they can contribute to

12 QS Intelligence Unit Consulting Service. 2020. URL: http://www.iu.qs.com/services/consulting/ (accessed 23.09.2020). 
changes in teaching delivery methods and even on some occasions influence educational standards (Interview 7).

The Global Education Program, a government-sponsored funding program that offers Russian citizens a chance to study abroad at leading foreign universities requires that students return to Russia upon completion of their studies to work according to their specialization for a period of three years. This program encourages students to acquire an international experience and expertise, turning them into experts, capable of promoting change and internationalization upon their return home.

The Megagrant project offers monetary grants to support scientific research projects at Russian institutions, which involve the world's leading scientists and aims at developing internationally competitive research. The Head of a laboratory created based on a Megagrant remarked: "Some of the leading researchers in Megagrants projects are foreigners coming from all over the world. They share their know-how with our team. Our leading researcher helps to conceive each of our publication projects, we discuss each paper with him, the methodology, the flow-narrative, he helps to select the target journal, offers his approach to data analysis, shares his expertise in his field, gives practical information about how to publish in foreign journals: all this is very valuable" (Interview 3).

These three projects reinforce the knowledge sharing promoted by Project 5-100. A number of foreign experts working in Russian universities can be directly traced back to Project 5-100 itself. An interviewee noted that MFTI had the ambitious target, in the framework of its Project 5-100, to open 50 new laboratories and that this goal was met because the staff renewed its contacts with the University's graduates who had emigrated. In the interviewee's own words: "This really worked out and many of our graduates returned to help. MFTI's progress in the ratings today is the result of the creation of these laboratories early on in the project" (Interview 8).

Universities were also required in the framework of Project 5-100 to identify foreign universities with a similar profile and interact with them. MFTI developed based on this requirement a close relationship with MIT: a team went to visit the university, attended training sessions, met with the Vice-Presidents and the administrative staff, and tried to understand what best practices would be applicable to MFTI. "We studied their online platform, their campuses, their economic system and their endowment" noted a respondent (Interview 8). A relationship was born and led to interaction at many different levels, with MIT and MFTI coordinators and professors forming together a Transnational Expertise and Experience Network capable of jointly promoting changes in the Russian university.

The 5-100 project office also organized training programs for the employees of the universities international departments: "they were sent to Europe and the United States to attend lectures by the world's most famous internationalization of higher education experts: Hans de Wit, Philip Altbach, Fiona Hunter, Laura Rumbley” (Interview 1). International experts, while they assume different roles and functions, play a significant role in sharing expertise and experience with Russian universities and supporting them in their ambition to attain excellence in higher education.

The impact of international actors sharing best practices in Project 5-100 can hardly be overestimated (see, Fig. 3). The platforms created by the government for international interaction (including the International Expert Committee, the 5-100 Project Office, etc.) and the rules governing the project (the monitoring of universities' progress through international ratings, the requirement to engage the services of external consultants etc.) allowed the initiative to deeply reform the universities involved. The combination of Russian and international specialists from universities, 
rating agencies, consultancy firms and governmental bodies created dense networks, which steered the implementation of Project 5-100 in line with the goal to increase the international competitiveness of Russian higher education and science.

Figure 3

Network Involved in Implementation of Project 5-100 on University Level

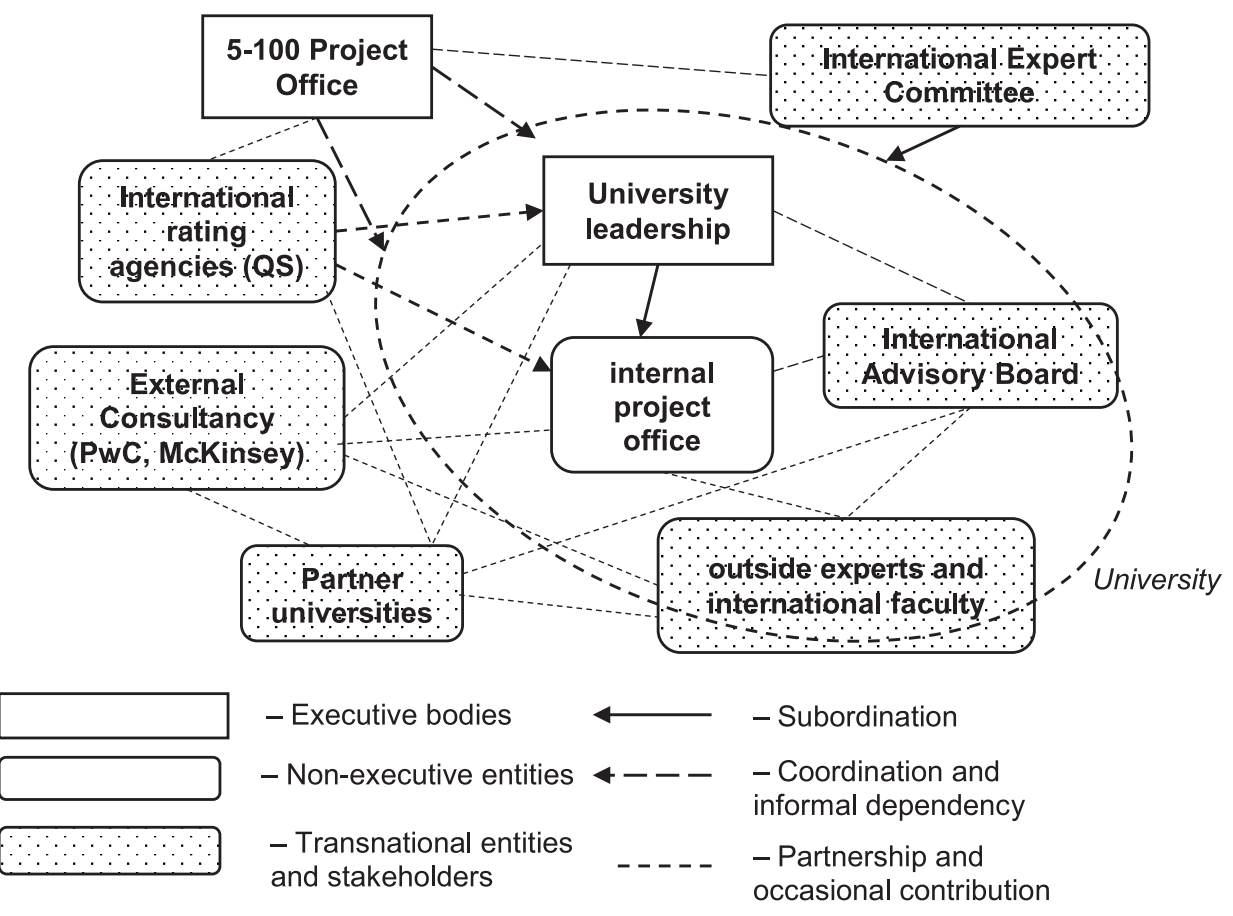

Source: authors.

They operated as TEENs, focusing on sharing expertise and know-how on a very granular level. It is also possible to conclude that the role of transnational ties during the implementation phase was even higher than during its adoption and required the engagement of a broader set of actors. Moreover, the transnational networks initiated by individual universities participating in Project 5-100 were characterized by a greater diversity of stakeholders and intensity of interaction than on the national level (compare Fig. 2 and 3).

\section{CONCLUSION}

By reviewing the conditions in which Project 5-100, the Russian excellence in higher education initiative emerged and the specificities of its design, this article seeks to inform the debate on how transnational networks contribute to the introduction of change through policy adoption and implementation. It contributes to the literature on policy networks by showing that transnational actors can help government implement long-aspired for systemic change and do not necessarily undermine state power as a large portion of the literature suggests.

Inspired from the international experience of creating world-class universities, Project 5-100 was designed and advocated by a policy network, involving actors 
from inside and outside the government. Its core comprised a small group of Russian officials and leaders of key universities who deliberately and effectively used international expertise for the development of a national project, which went beyond the country's previous experience. The role of transnational connections increased in the implementation phase after the adoption of the relevant national regulations.

This key feature of Project 5-100, the planned integration of international actors in helping implement the initiative on the ground, not only sets it apart from previous initiatives but can also influence the design of future projects in Russia and abroad. As the new "Priorities 2030" is being designed at governmental level to replace Project $5-100$, it is important not only to take into account the new political orientations but also to recognize that the achievements of Project 5-100 were largely due to its focus on promoting international networking. A change of orientation promoting local content could lead to unexpected regressions.

DOI: $10.17976 / j p p s / 2021.05 .02$

\title{
ТРАНСНАЦИОНАЛЬНЫЕ ПОЛИТИЧЕСКИЕ СЕТИ И ИЗМЕНЕНИЯ ПОСРЕДСТВОМ ИНТЕРНАЦИОНАЛИЗАЦИИ (опыт проекта 5-100)
}

\section{А. Виньо, И.А. Истомин, А.А. Байков, Е. Калюжнова}

ВИНьО Анн, кандидат политических наук, $\mathrm{PhD}$, доцент кафедры английского языка №1, МГИМО МИД России, Москва, email: vigneau.a@my.mgimo.ru; ИСТОМИН Игорь Александрович, кандидат политических наук, доцент кафедры прикладного анализа международных проблем, МГИМО МИД России, Москва; приглашенный исследователь Центра Дэвиса, Гарвардский университет, Кембридж, Macc. (США), email: i.istomin@inno.mgimo.ru; БАЙКОВ Андрей Анатольевич, кандидат политических наук, доцент, проректор по научной работе, декан факультета международных отношений, МГИМО МИД России, Москва; приглашенный профессор Бизнес-школы Хенли, Рединг (Великобритания), email: baykov@mgimo.ru; КАЛЮЖНОВА Елена, $\mathrm{PhD}$, профессор, директор Центра евроазиатских исследований Бизнес-школы Хенли, Рединг (Великобритания), email: y.kalyuzhnova@henley.ac.uk

Виньо А., Истомин И.А., Байков А.А., Калюжнова Е. Транснациональные политические сети и изменения посредством интернационализации (опыт проекта 5-100). - Полис. Политические исследования. 2021. № 5. C. 8-24. https://doi.org/10.17976/jpps/2021.05.02

Статья поступила в редакцию: 15.03.2021. Принята к публикации: 20.05.2021.

\begin{abstract}
Аннотация. В настоящей статье рассматриваются политические взаимодействия, обусловившие запуск и реализацию проекта 5-100 - инициативы, направленной на повышение международной конкурентоспособности российских университетов. Хотя проект 5-100 уже освещался в научной литературе, его истоки и особенности организации не становились предметом специального рассмотрения. Исследование концентрируется на роли российских и зарубежных специалистов, утверждая, что их успешное и органичное сотрудничество повлияло как на архитектуру, так и на реализацию проекта. Оно опирается на теоретические подходы к изучению политических сетей, акцентирующие значение горизонтальных связей между участниками, находящимися в различных структурных позициях и обладающими различными компетенциями. Авторы указывают, что сеть сторонников проекта на национальном и университетском уровнях сыграла решающую роль во внедрении системных изменений. Вдохновленный международным опытом построения университетов мирового уровня, проект 5-100 был задуман небольшой, но влиятельной группой руководителей вузов и высокопоставленных сотрудников государственных ведомств, активно задействовавших потенциал транснациональных связей для внедрения международного опыта при разработке ключевого национального проекта, способного глубоко преобразовать систему высшего образования страны. При этом зарубежная экспертиза оказалась особенно широко востребована на этапе реализации проекта, а не в момент принятия стратегических решений. Таким образом, проведенное исследование демонстрирует значение транснациональных экспертных сетей при проведении изменений в значимых областях
\end{abstract}


государственной политики. Полученные выводы обосновываются с опорой на анализ широкого круга документов и серию исследовательских интервью.

Ключевые слова: Россия, проект 5-100, высшее образование, интернационализация, транснациональные сети убеждений, транснациональные экспертные сети.

\section{References}

Adam S., Kriesi H. 2007. The Network Approach. - Theories of the Policy Process. Ed. by P. Sabatier. Oxon: Routledge. P. 129-154.

Agasisti T., Shibanova E., Platonova D., Lisyutkin M. 2018. The Russian Excellence Initiative for Higher Education: an Econometric Evaluation of Short-Term Results. Higher School of Economics Research Paper No. WP BRP 201/EC/2018. https://doi.org/10.2139/ssrn.3272809

Altbach P.G., Salmi J. 2011. The Road to Academic Excellence: The Making of World-Class Research Universities. Direction in Development; Human Development. World Bank. https://doi. org/10.1596/9780821388051_FM

Bevir M. 2009. Key Concepts in Governance. London: Sage. 218 p.

Börzel T.A. 1998. Organizing Babylon - On the Different Conceptions of Policy Networks. - Public Administration. Vol. 76. No. 2. P. 253-273. https://doi.org/10.1111/1467-9299.00100

Crowley-Vigneau A., Baykov A., Kalyuzhnova Y. 2020. Implementation of International Norms in Russia: The Case of Higher Education. - Higher Education in Russia. Vol. 29. No. 8/9. P. 39-54. https:// doi.org/10.31992/0869-3617-2020-29-8-9-39-54

Enroth H. 2011. Policy Network Theory. - The Sage Handbook of Governance. London: Sage. P. 19-35. https://doi.org/10.4135/9781446200964.n2

Eschle C. 2001. Globalizing Civil Society? Social Movements and the Challenge of Global Politics from Below. - Globalization and Social Movements. London: Palgrave Macmillan. P. 61-85. https://doi. org/10.1057/9780230554443_4

Finnemore M. 1996. National Interests in International Society. Ithaca, N.Y.: Cornell University Press. 154 p.

Finnemore M., Sikkink K. 1998. International Norm Dynamics and Political Change. - International Organization. Vol. 52. No. 4. P. 887-917. https://doi.org/10.1162/002081898550789

Froumin I., Leshukov O. 2015. National-Regional Relationships in Federal Higher Education Systems: The Case of Russian Federation. - Higher education forum Hiroshima University. No. 12. P. 77-94.

Globalizing Civic Engagement: Civil Society and Transnational Action. 2012. Ed. by J.D. Clark. Oxon: Routledge. 194 p.

Hafner-Burton E.M., Kahler M., Montgomery A.H. 2009. Network Analysis for International Relations. International Organization. Vol. 63. No. 3. P. 559-592. https://doi.org/10.1017/s0020818309090195

Heclo H. 1978. Issue Networks and the Executive Establishment. - The New American Political System. Ed. by A. King. Washington, DC: American Enterprise Institute. P. 413-422.

Kaldor M. 2003. The Idea of Global Civil Society. - International Affairs. Vol. 79. No. 3. P. 583-593. https://doi.org/10.1111/1468-2346.00324

Keane J. 2003. Global Civil Society? Cambridge: Cambridge University Press. 220 p.

Keck M.E., Sikkink K. 1998. Activists Beyond Borders, Advocacy Networks in International Politics. New York: Cornel University Press. 228 p. https://doi.org/10.7591/9780801471292

Kirpotin S.N., Callaghan T.V. et al. 2018. Russian-EU Collaboration via the Mega-transect Approach for Large-Scale Projects: Cases of Rf Federal Target Programme and SIWA JPI Climate EU Programme. International Journal of Environmental Studies. Vol. 75. No. 3. P. 385-394. https://doi.org/10.1080/002072 33.2018.1429131

Marsh D., Smith M. 2000. Understanding Policy Networks: Towards a Dialectical Approach. - Political Studies. Vol. 48. No. 1. P. 4-21. https://doi.org/10.1111/1467-9248.00247

Process Tracing. 2015. Ed. by A. Bennett, J.T. Checkel. Cambridge: Cambridge University Press. 329 p.

Rhodes R.A.W. 1997. Understanding Governance: Policy Networks, Governance, Reflexivity and Accountability. Buckingham: Open University. 235 p.

Salmi J. 2009. The Challenge of Establishing World-Class Universities. Directions in Development; Human Development. World Bank. URL: https://openknowledge.worldbank.org/handle/10986/2600 License: CC BY 3.0 IGO.

Smolentseva A. 2015. Globalization and the Research Mission of Universities in Russia. - Higher Education in the BRICS Countries. Higher Education Dynamics. Vol. 44. Ed. by S. Schwartzman, R. Pinheiro, P. Pillay. Dordrecht: Springer. https://doi.org/10.1007/978-94-017-9570-8_20 
The Third Force: The Rise of Transnational Civil Society. 2012. Ed. by A.M. Florini. Washington, D.C.: Brookings Institution Press. 295 p.

Degterev D.A. 2015. Net-analysis of International Relations. - Vestnik Sankt-Peterburgskogo universiteta. Politologiya. Mezhdunarodnye otnosheniya. № 4. P. 119-138. (In Russ.)

Gutorov V.A. 2015. Politics and Education: Historical Tradition and Modern Transformations. - Polis. Political Studies. No.1. P. 9-29. (In Russ.) https://doi.org/10.17976/jpps/2015.01.02

Mikhailova O.V. 2013. Seti v politike i gosudarstvennom upravlenii [Networking in Politics and in Government]. Moscow: ID KDU. 332 p. (In Russ.)

Smorgunov L.V. 2001. Net-Approach Towards Politics and Government. - Polis. Political Studies. No. 3. P. 103-112. (In Russ).

Setevoi analiz publichnoi politiki [Network Analysis of Public Policy]. 2013. Ed. by L.V. Smorgunov. Moscow: RG-Press. 320 p. (In Russ.)

\section{Литература на русском языке}

Дегтерев Д.А. 2015. Сетевой анализ международных отношений. - Вестник Санкт-Петербургского университета. Политология. Межжднародные отношения. № 4. С. 119-138.

Гуторов В.А. 2015. Политика и образование: историческая традиция и современные трансформации. - Полис. Политические исследования. № 1. С. 9-29. https://doi.org/10.17976/jpps/2015.01.02

Михайлова О.В. 2013. Сети в политике и государственном управлении. М.: ИД КДУ. 332 с.

Сморгунов Л.В. 2001. Сетевой подход к политике и управлению. - Полис. Политические исследования. № 3. С. 103-112.

Сетевой анализ публичной политики. 2013. Под ред. Л.В. Сморгунова. М.: РГ-Пресс. 320 с.

Appendix 1

List of Expert Interviews

\begin{tabular}{|l|l|l|c|l|c|c|}
\hline $\begin{array}{l}\text { Place of work } \\
\text { place of } \\
\text { work }\end{array}$ & $\begin{array}{c}\text { Presition } \\
\text { Nationality }\end{array}$ & $\begin{array}{l}\text { Interview } \\
\text { Language }\end{array}$ \\
\hline 1 & F & $\begin{array}{l}\text { Project 5-100 } \\
\text { Project Office }\end{array}$ & $/$ & Expert & Russian & Russian \\
\hline 2 & M & U.S. university & $/$ & Professor & U.S. & English \\
\hline 3 & M & Russian university & $/$ & Director & Russian & Russian \\
\hline 4 & M & Russian university & $/$ & Vice-Rector & U.S. & English \\
\hline 5 & F & Russian university & $/$ & Director & Russian & Russian \\
\hline 6 & F & Russian university & $/$ & Senior Director & Russian & Russian \\
\hline 7 & M & Russian university & $/$ & Head of Institute & Russian & English \\
\hline 8 & M & Russian university & $/$ & Vice-Rector & Russian & Russian \\
\hline 9 & F & Russian university & $\begin{array}{l}\text { Ministry } \\
\text { of Higher } \\
\text { Education }\end{array}$ & $\begin{array}{l}\text { Head } \\
\text { of Department }\end{array}$ & Russian & Russian \\
\hline 10 & M & $\begin{array}{l}\text { Ministry of Higher } \\
\text { Education }\end{array}$ & $/$ & $\begin{array}{l}\text { Aide } \\
\text { to the Ministry }\end{array}$ & Russian & Russian \\
\hline 11 & F & Research Centre & $/$ & Acting Director & Russian & Russian \\
\hline 12 & M & Consultancy firm & $/$ & Consultant & Russian & Russian \\
\hline
\end{tabular}

Note: One of the authors conducted twelve expert interviews in 2019-2020 with specialists in higher education involved in the conception and implementation of Russian Project 5-100. Transcribed and coded, the interviews and findings reveal new factual information about Project 5-100 and highlight the perception of the project from the point of view of different stakeholders. 